\section{TREATMENT OF HYPERBILIRUBINEMIA: VARIOUS TECHNOLOGIES AND CHALLENGES}

\author{
Esmaeil Salimia,b,c, Azadeh Ghaee ${ }^{*}$, Ahmad Fauzi Ismailb*, Mohd \\ Hafiz Dzarfan Othmanb
}

aDepartment of Life Science Engineering, Faculty of New Sciences and Technologies, University of Tehran, P.O. Box: 143951374, Tehran, Iran

bAdvanced Membrane Technology Research Center (AMTEC), Universiti Teknologi Malaysia, 81310 UTM Johor Bahru, Johor, Malaysia

cFaculty of Materials and Chemical Engineering, Shahrood University of Technology, P. O. Box: 3619995161, Semnan, Iran
Article history

Received

21 January 2017

Received in revised form

19 January 2018

Accepted

15 March 2018

Published online

1 August 2018

*Corresponding authors afauzi@utm.my

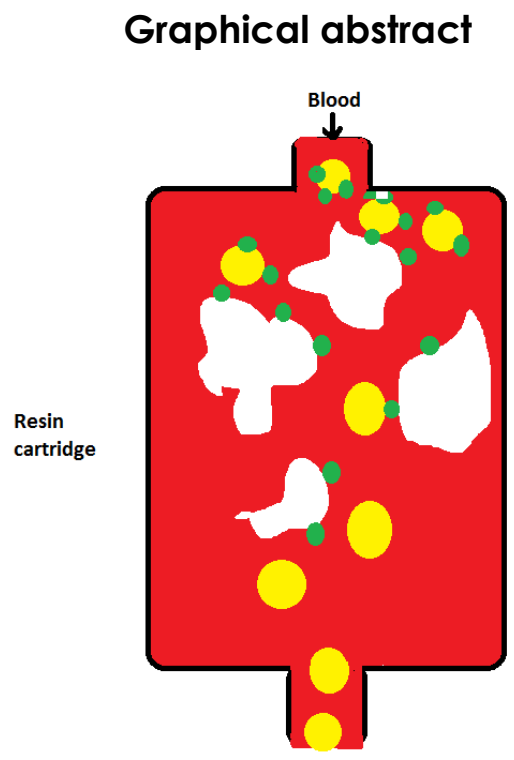

\begin{abstract}
Bilirubin removal from blood and curing patients suffering from hyperbilirubinemia by surgery, medication or interventional therapies was common, previously. Alternative bilirubin separation techniques such as plasma exchange, affinity chromatography and etc., are efficient in reducing high levels of bilirubin with fewer side effects. However, due to the various causes and complications associated with hyperbilirubinemia, different strategies are needed for the treatment. This article offers a historical overview on these strategies, challenges and also outlines the technological advantages and disadvantages associated with various bilirubin removal techniques.

Keywords: Hyperbilirubinemia, blood purification, affinity chromatography, overview, therapy
\end{abstract}

\begin{abstract}
Abstrak
Penyingkiran bilirubin dari darah dan cara mengubati pesakit yang menderita penyakit hiperbilirubinemia dengan pembedahan, ubat-ubatan atau terapi intervensi adalah kaedah biasa yang kerap digunakan sebelum ini. Teknik alternatif pemisahan bilirubin yang lain seperti pertukaran plasma, kromatografi afiniti dan lain-lain, adalah berkesan dalam mengurangkan jumlah bilirubin yang tinggi dengan kesan sampingan yang lebih rendah. Walau bagaimanapun, disebabkan pelbagai faktor dan komplikasi yang berkaitan dengan penyakit hiperbilirubinemia, strategi yang berbeza diperlukan untuk rawatan penyakit ini. Artikel ini menerangkan gambaran keseluruhan tentang strategi, cabaran dan juga menggariskan kelebihan dan kekurangan teknologi yang berkaitan dengan pelbagai teknik penyingkiran bilirubin.

Kata kunci: Hyperbilirubinemia, blood purification, kromatografi afiniti, gambaran, terapi
\end{abstract}




\subsection{INTRODUCTION}

Life-threatening syndromes such as acute liver failure (ALF) and acute-on-chronic liver failure (ACLF) which are usually induced by drug toxicity, hepatitis or idiosyncratic reactions, have poor diagnosis with a mortality rate of over $60 \%$ [1]. One of the main reasons of the patient's death who suffer from ALF is the reduced ability of hepatocytes to detoxify the blood. Consequently, concentration of waste compounds especially hydrophobic albumin-bound molecules such as bilirubin significantly increases in the blood [2] which can affect the liver function and cause more damage. Clearance of Bilirubin (Figure. 1) which is a potentially toxic catabolic product of hemoglobin occur upon binding with glucuronic acid in the hepatocytes and excretion into the bile [3]. Usually, albumin molecules in blood play the carrier role for bilirubin and transport it toward the liver [4]. But, under some physiological disorders such as jaundice, hemolytic anemia [5] and genetic deficiency in newborn infants, the unconjugated bilirubin (UB) concentration will be escalated in plasma [4], which can interfere with the normal functioning of the hepatocytes and eventually manifests systemic toxicity [6]. Moreover, after crossing the serum level of the bilirubin from threshold level (hyperbilirubinemia), subsequent events such as impairing cellular function, inhibiting respiration and finally fatal Kernicterus may happen [6, 7]. So, developing an extracorporeal method to separate bilirubin from the blood of ALF and ACLF patients is crucial.<smiles>C=CC1=C(C)/C(=C\c2[nH]c(Cc3[nH]c(/C=C4/NC(=O)C(C)=C4C=C)c(C)c3CCC(=O)[O-])c(CCC(=O)[O-])c2C)NC1=O</smiles>

Figure 1 Chemical structure of bilirubin

Patients with Mild case of hyperbilirubinemia can generally be treated by phototherapy effectively [8], but for severe cases, more drastic measures, such as plasma exchange, hemodialysis, hemoperfusion and etc. is needed. Considering the reality that usually small hydrophilic molecules are able to pass through the hemodialysis membranes, but bilirubin as a hydrophobic compound which is normally conjugated to albumin cannot be efficiently separated, so researchers focused on other strategies for bilirubin removal, which will be discussed in details in the following. Although several reviews $[9,10]$ have been published by focusing on the removal of protein bound toxins, however, this review is meant to provide a precise overview on bilirubin removal as an important and challenging toxin, through extra-corporeal strategies, which is believed that has not been discussed before.

\subsection{BLOOD EXCHANGE}

Replacement of the patient's blood with the same amount of donor type-compatible whole blood, is usually called blood exchange or exchange transfusion (Figure 2), which can lower the toxic burden, replace erythrocytes and correct anemia [11]. Ionized hypocalcemia, transfusion reactions and hypothermia are among the complications of this technique. This strategy could not increase the survival rate and hence could not receive popular acceptance in comparison with the recently developed approaches. It was only employed for specific patients to inverse hepatic coma temporarily [12].

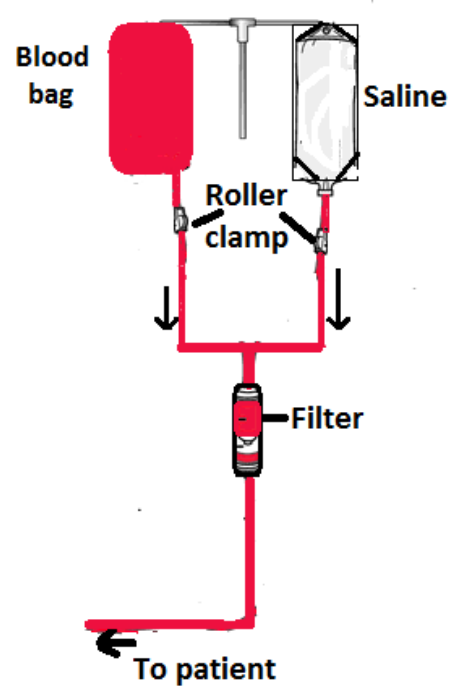

Figure 2 Blood transfusion system

At the same time and as an alternative, plasma exchange was used to recover patients from fulminant hepatic failure (FHF). Removing plasma toxins by substitution with healthy plasma was reported by Lepore et al., [13, 14] for the first time. They examined patients with acute hepatic failure and reported neurological improvement in two out of nine prior to death. Patient survival of $75 \%$ was demonstrated by Buckner et al., [15] who treated four patients with $10 \mathrm{~L}$ plasma exchanges per day for 3-36 days. In spite of the considerable complications associated with this method, such as toxicity, infection, respiratory problems, insufficiency and brain disfunction, plasma exchange are being used relatively frequently as one of the main cure for patients suffering from FHF.

\subsection{AFFINITY CHROMATOGRAPHY}

Affinity separation is an efficient and eminent purification method, which adsorb and separate molecules based on the highly specific binding between the counterparts, as shown in Figure 3 [16]. Most of the molecules can be purified by this technique, based on their own biological functions rather than individual chemical or physical 
properties. In recent years, this strategy has turned into an effective method to remove toxins from human blood [18]. A ligand which possess specific recognition ability is immobilized on an appropriate insoluble supporting matrix (carrier) such as polyacrylamide, cross-linked dextran, porous glass, silica gel, cellulose, and oxides of various metals [19]. Also numerous specific functional molecules such as antibodies, proteins, amino acids, enzymes, coenzymes, cofactors, nucleic acids, oligopeptides and oligonucleotides can be considered as ligands. The effectivity of affinity chromatography matrix depends on various factors such as chemical structure of the matrix, reactive functional groups density on the matrix surface, size and swelling index of particles, which can influence the immobilization reactions. Dependency of every system on these variables is different.

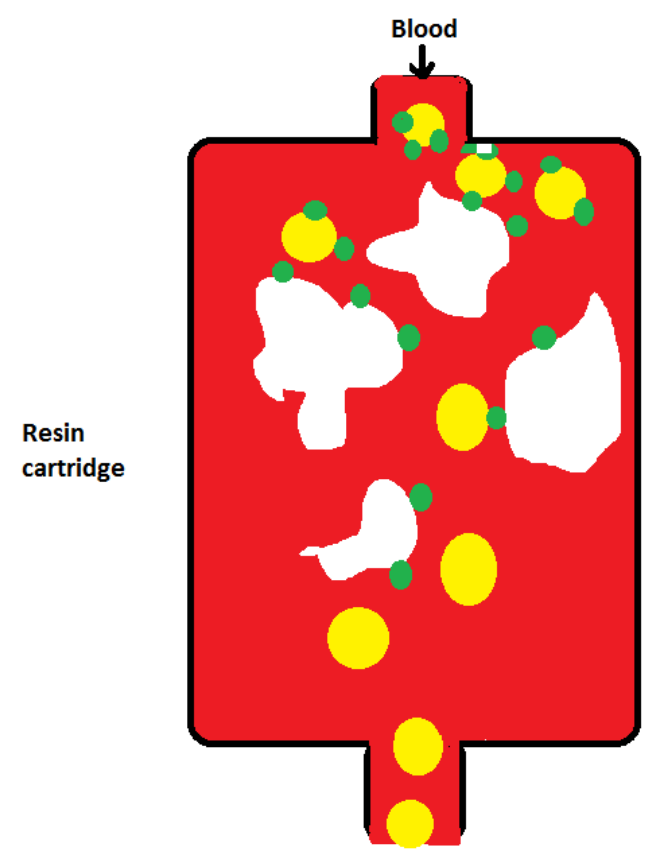

Figure $\mathbf{3}$ Simple process of the affinity separation

In spite of the fact that each bovine serum albumin (BSA) molecule has around 12 binding sites for bilirubin, but bilirubin molecules bind only on two of these sites tightly [20], so a ligand should be able to compete with these binding sites on albumin in order to remove unconjugated bilirubin successfully. Generally, affinity chromatography can be categorized into column and membrane chromatography, as discussed below.

\subsection{Column Chromatography}

Among the usual methods applied for removing bilirubin from plasma, Column chromatography, is considered as a reasonable option for the treatment of severe hyperbilirubinemia due to its good biocompatibility and high efficiency. In this technique, which is also called hemoperfusion, blood is circulated through an extracorporeal unit containing an adsorption column packed with particle adsorbents. Generally, the adsorbents which are being used in hemoperfusion for bilirubin removal require high adsorption capacity, easy to sterilize, adequate biocompatibility and blood compatibility as well as sufficient chemical, physical and mechanical stability [21].

Since late 1970s, several researchers have tried to develop different kinds of specific and non-specific adsorbents such as activated agar [22], charcoal [23], polylysine immobilized chitosan beads [24], Cibacron Blve F3GA immobilized adsorbents [25], $\beta$ cylodextrin supported by partially aminated polyacrylamide gel (30), bilirubin (BR) imprinted poly(methacrylic acidco-ethyleneglycol dimethacrylate) [26], anion exchange resins [27], cross-linked chitosan resins [28], and albumin immobilized polymeric adsorbents [29]. For example, Davies et al. [30] claimed that adsorption capacity of an anion-exchange resin (BR-601) for albuminbound bilirubin removal depends on temperature and by increasing the temperature up to $42^{\circ} \mathrm{C}$, adsorption will raise up to $80 \mathrm{mg}$ bilirubin/g resin. Different kinds of adsorbent with various adsorption capacities have been investigated in reports for bilirubin separation. Komissarova et al. [31] detoxified the blood by employing iron-based magnetic beads and adsorbed bilirubin up to $70.8 \mathrm{mg} / \mathrm{g}$. Alvarez et al. [26] adsorbed $3.1 \mathrm{mg} / \mathrm{g}$ BR on the BSA-immobilized poly (butadiene-hydroxyethyl methacrylate) particles. Bilirubin adsorption up to $0.83 \mathrm{mg} / \mathrm{g}$ was reported by Syu et al., on the BR imprinted poly (methacrylic acid co-ethylene glycol dimethacrylate) beads [32]. Wang et al., [33] immobilized $\beta$-cyclodextrin on partially aminated polyacrylamide gel could adsorb bilirubin around $42.4 \mathrm{mg} / \mathrm{g}$. Wu and Brown modified polyacrylamide resins with amine and reported that the BR adsorption efficiency improved by increasing the number of amino groups [34].

Chandy and Charma could obtain bilirubin separation efficiency of around $0.66-1.13 \mathrm{mg} / \mathrm{g}$ by employing the polylysine-immobilized chitosan beads [24]. Henning et al. [35] grafted basic amino acids on polyamide resins and could separate bilirubin up to 5-80 $\mathrm{mg} / \mathrm{g}$. Zhu et al. [36] reported that bilirubin adsorption can be improved up to $0.2-75$ mg bilirubin /g by coating polyamide resin with polypeptide (i.e., poly-Llysine, poly-D-lysine and polyL-ornithine). The maximum bilirubin adsorption that kocakulak et al. [37], could achieve was 14.8-18.9 $\mathrm{mg}$ bilirubin / $\mathrm{g}$ polymer.

Ju et al. [38, 39], used sodium benzoate in order to break the tight binding of BR with human albumin (HA) and enhance the BR removal efficiency in hemoperfusion. The results indicated that the drugs could form a ternary BR-HA-drug complex or displace $B R$ from $H A$ and increase the BR adsorption capacity of the adsorbents in hemoperfusion. Bilirubin removal was also investigated on a variety of highly-porous adsorbents such as activated carbon and mesoporous silica materials [40].

However, traditional column chromatography has been employed for decades extensively, but it is currently under scrutiny. Despite its refined quality and high resolving power, uses of microbeads adsorbents in packed-bed columns have several 
technical limitations such as: difficulty in mass transfer, prolonging the therapeutic time and low selectivity. Blood cells entrapment among the beads in the column can reduce the flow rate and finally block the column completely.

Thus, molecular imprinting technology has emerged as a simple and powerful method that produces artificial receptors with predetermined ligand selectivity [41]. In this technique, target molecules or their analogous are used as templates to form recognition sites within a polymer. Target molecules are mixed with the functional monomers during polymerization and finally, washed out and leave specific cavities. The molecular memory which is introduced into the polymer during this procedure will be able to rebind with the target specifically (Figure 4) [42].

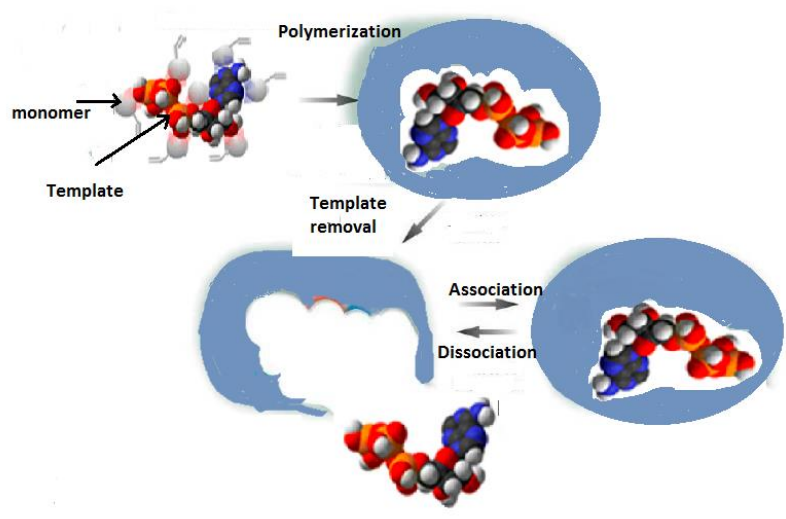

Figure 4 Schematic representation of the molecular imprinting process

In order to achieve a successful preparation of a molecularly imprinted polymer (MIP), different parameters such as monomers, cross-linkers and also polymerization conditions should be optimized for a given analyte. Also, selectivity is an important issue, which should be taken into consideration in dealing with binding capacity of a MIP with its target molecules. Various kinds of MIP systems are manufactured for bilirubin recognition. Yang et al. [43] used $\beta$-cyclodextrin as functional monomer and bilirubin as template and could prepare bilirubinimprinted polymer. The prepared bilirubin-imprinted $\beta$-cyclodextrin polymer could adsorb bilirubin from high concentrated bilirubin aqueous solutions (35mg/dL), up to $42-46 \mathrm{mg} / \mathrm{g}$ MIP. Syu et al. [32] synthesized poly (methacrylic acid-co-ethylene glycol dimethacrylate) polymer by UV-irradiation and heat treatment in methyl dichloride as solvent. The prepared polymer presented adsorption efficiency of around $1.06 \mathrm{mg} / \mathrm{g}$ MIP for bilirubin separation from aqueous solutions at $\mathrm{pH} 4.0$ and 0.24-0.85 mg/g MIP from rat serum and bile samples [44]. Wu and Syu employed photo-graft surface polymerization technique to prepare bilirubin imprinted poly (4-vinylpyridine-divinyl benzene) film on the gold electrode surface of quartz crystal microbalance chip. They could separate bilirubin from a solution of $12 \mathrm{mg}$ bilirubin / $\mathrm{dL}$ with an efficiency of $62 \mathrm{mg} / \mathrm{g}$ [45].

Baydemir et al. [46], investigated bilirubin adsorption capacity of highly porous BR-MIP cryogel of poly(hydroxyethylmethacrylate-N-methacryloyl-(I)tyrosine methylester (MAT) in a practical extracorporeal therapy and reported an adsorption capacity of $(3.6 \mathrm{mg} / \mathrm{g})$. They also demonstrated that advantages like high porosity, short diffusion path and residence time and low pressure drop can turn cryogels to a good candidate for toxic substances removal from human blood.

Concerning the MIPs performance, some deficiencies require to be further improved, such as inhomogeneous morphology and poor reproducibility of the imprinted sites, low affinity and binding rate [47]. In addition, diversity of suitable functional monomers and cross-linking agents which can satisfy the needs of molecular recognition is not sufficient. All mentioned insufficiencies can restrict the real applications of MIPs critically.

Table 1 represents the adsorption capacity of some of the affinity adsorbents, which have been investigated in literature. Observed differences among bilirubin adsorption capacities can be related to the characteristics of the adsorbents such as morphology, available surface area, modifying agent, functional groups density and also experimental parameters.

Table 1 Comparison of the bilirubin adsorption capacity of various beads

\begin{tabular}{|c|c|c|c|}
\hline Material & $\begin{array}{l}\text { Ligand/ } \\
\text { interaction }\end{array}$ & $\begin{array}{c}\text { Adsorption } \\
\text { capacity } \\
\text { (mg/g) }\end{array}$ & Ref \\
\hline $\begin{array}{l}\text { Polybutadienehydroxyethyl } \\
\text { methacrylate- } \\
\text { epichlorohydrin copolymer }\end{array}$ & BSA & 3.10 & [26] \\
\hline $\begin{array}{c}\text { Chitosan } \\
\text { beads }\end{array}$ & polylysine & 1.5 & {$[24]$} \\
\hline $\begin{array}{c}\text { Silica } \\
\text { nanotubes }\end{array}$ & Arginine & 63.6 & {$[48]$} \\
\hline $\begin{array}{l}\text { Microporous membranous } \\
\text { poly(tetrafluoroethylene) } \\
\text { (MPTFE capillary) and } \\
\text { commercially available } \\
\text { common PTFE capillaries } \\
\text { (CPTFE capillary) }\end{array}$ & HAS & $\begin{array}{l}\text { MPTFE }=71.2 \\
\text { CPTFE }=53.8\end{array}$ & [49] \\
\hline $\begin{array}{l}\text { Partially aminated } \\
\text { polyacrylamide }\end{array}$ & $\begin{array}{l}\beta \text {-cyclo- } \\
\text { dextrin }\end{array}$ & 42.2 & [33] \\
\hline $\begin{array}{l}\text { multi-walled carbon nano- } \\
\text { tubes (MWCNTs)/iron } \\
\text { oxides magnetic } \\
\text { composites }\end{array}$ & - & 263.16 & {$[50]$} \\
\hline $\begin{array}{c}\text { Amine/methyl } \\
\text { bifunctionalized } \\
\text { mesoporous silica(SBA-15) }\end{array}$ & - & 300 & {$[40]$} \\
\hline Nanocrystalline $\mathrm{TiO}_{2}$ film & - & 25 & {$[51]$} \\
\hline
\end{tabular}


Table 1(Continue)

\begin{tabular}{|c|c|c|c|c|c|c|c|}
\hline \multicolumn{4}{|l|}{ Table 1(Continue) } & \multirow{2}{*}{ Material } & \multirow{2}{*}{$\begin{array}{l}\text { Ligand/ } \\
\text { interaction }\end{array}$} & \multirow{2}{*}{$\begin{array}{l}\text { Adsorption } \\
\text { capacity } \\
\text { (mg/g) }\end{array}$} & \multirow{2}{*}{ Ref } \\
\hline & & Adsorption & & & & & \\
\hline Material & interaction & $\begin{array}{c}\text { capacity } \\
(\mathrm{mg} / \mathrm{g})\end{array}$ & Ref $^{-}$ & $\begin{array}{l}\text { Poly(glycidyl methacrylate } \\
\text { divinylbenzene) copolymer }\end{array}$ & Albumin & 30 & [65] \\
\hline PHEMAT/MIP cryogel & $\begin{array}{l}\text { Molecular } \\
\text { recognition }\end{array}$ & 3.6 & {$[46]$} & \multirow[b]{2}{*}{ PHEMA } & \multirow{2}{*}{$\begin{array}{l}\text { Cibacron } \\
\text { Blue F3GA }\end{array}$} & \multirow[b]{2}{*}{$6.8-32.5$} & \multirow{2}{*}{$\begin{array}{l}{[37,} \\
65]\end{array}$} \\
\hline poly(MAA-co-EGDMA)/MIP & & & & & & & \\
\hline $\begin{array}{c}\text { Poly(meth acrylic acid-co- } \\
\text { ethylene glycol }\end{array}$ & $\begin{array}{l}\text { Molecular } \\
\text { recognition }\end{array}$ & 0.27 & {$[52]$} & PHEMA & HAS & 64.7 & [66] \\
\hline $\begin{array}{c}\text { dimethylacrylate) } \\
\beta \text {-cyclodextrin }\end{array}$ & $\begin{array}{l}\text { Molecular } \\
\text { recognition }\end{array}$ & 46 & {$[43]$} & Anion-exchange resin & $\begin{array}{l}\text { Ion } \\
\text { exchange }\end{array}$ & $4.0-80$ & [30] \\
\hline poly(HEMA-MAT)/MIPa & $\begin{array}{l}\text { Molecular } \\
\text { recognition }\end{array}$ & 3.41 & [53] & $\begin{array}{l}\text { PHEMA magnetic } \\
\text { beads }\end{array}$ & HAS & 88.3 & [67] \\
\hline Poly(MAA-EGDMA)/MIP & $\begin{array}{l}\text { Molecular } \\
\text { recognition }\end{array}$ & 1.04 & {$[44]$} & Poly(St-DVB) & $\begin{array}{c}\text { Hydrophobi } \\
\text { C } \\
\text { interactions }\end{array}$ & 1.4 & [68] \\
\hline $\begin{array}{c}\text { PHEMA-MIP } \\
\text { composite cryogel }\end{array}$ & $\begin{array}{l}\text { Molecular } \\
\text { recognition }\end{array}$ & 10.3 & {$[54]$} & PTFE-PGMA-PEI & $\begin{array}{l}\text { Electrostatic } \\
\text { interactions }\end{array}$ & 9.6 & [69] \\
\hline Poly(VP-DVB)/MIP & $\begin{array}{l}\text { Molecular } \\
\text { recognition }\end{array}$ & 62 & {$[45]$} & Carbon nanotubes & $\begin{array}{l}\text { Electrostatic } \\
\text { interactions }\end{array}$ & 9.7 & [70] \\
\hline $\begin{array}{l}\text { polyamide hollow-fiber } \\
\text { poly(glycidyl methacrylate) } \\
\text { (PGMA) beads }\end{array}$ & $\begin{array}{l}\text { Cibacron } \\
\text { Blue F3GA }\end{array}$ & 48.9 & {$[56]$} & \multicolumn{4}{|c|}{$\begin{array}{ll}- & \text { Human serum albumin (HSA) } \\
\text { - } & \text { Polyethyleneimine (PEI) } \\
\text { - } & \text { Glycidyl methacrylate (GMA), acrylamide (AM) and N,N } \\
& \text { N-methylene bisacrylamide (MBA). } \\
\text { - } & \text { Hydroxyethyl celluloses (HEC), (2- } \\
& \text { hydroxyethylmethacrylate (HEMA) and glycidyl } \\
& \text { methacrylate (GMA) }\end{array}$} \\
\hline
\end{tabular}

SWNHS surface-

(GMA/AM/MBA) microbeads

(MPTFE) capillaries

Amino-modified silica particles

Silica particles

Cellulose acetate fiber

Hollow mesoporous carbon spheres

Octyl functionalized silica Phenyl functionalized silica Urea-propyl functionalized silica

Silica particles

Polyacrylamide oxidization

PEI

HSA

BSA

polymetha

crylate

guanidine

polyacrylat

e guanidine

Cibaron

Blue F3GA

High

surface

area, large

pore size

with narrow

distribution

Octyltrietho

xysilane

Phenyltrieth

oxysilane 1-

[3-

(trimethoxys

ilyl)- propyl]

urea

Polyvinyl

pyrrolidone

$0.65-1.96$

$-0.73$

$0.51-0.95$

$0.95-2.01$

$0.48-0.64$

$0.94-1.10$

Poly(L-

lysine)

Poly(D-

lysine)

Poly (L-

$0.2-75$

\subsection{Membrane Chromatography}

Micro-porous membranes as an alternative to the particle adsorbents have received considerable interests in biomedical fields recently [71]. High surface area, short diffusion path, minimal denaturation of product, reduced mass transfer resistance and low-pressure drop are among their advantages [55]. Membrane material and its preparation procedure control the factors influencing the efficiency of chromatography. In addition to high hydrophilicity, high biological, chemical and mechanical resistance, minimum adsorption of nonspecific proteins and high density of reactive groups for ligands immobilization [72], a suitable membrane in affinity chromatography should also possess uniform thickness and narrow pore size distribution. Such a affinity membrane will improve the loading volume, solute recovery and also ligand immobilization efficiency [73, 74]. The researches on BR removal based on membrane adsorbents are particularly focused on the modification methods of the membranes [75], optimization of adsorption parameters [18] and improvement of adsorption models [76].

[63] An immobilized ligand on the affinity membrane requires to being stable, bio-specific, easily immobilized, preserve its biological activity, inexpensive and non-toxic (Figure 5). Considering that biological ligands are expensive and extremely specific in most cases, so Senel et al. [55] proposed dye-ligands as a significant alternative, which can be used in affinity membranes. They are inexpensive, commercially available and can be attached to different matrixes easily. Senel and his coworkers immobilized Cibacron Blue F3GA on the commercially available polyamide hollow-fiber 
membrane in alkaline medium and could separate bilirubin up to $48.9 \mathrm{mg} / \mathrm{g}$ at $37^{\circ} \mathrm{C}$. Song et al. [48, 75] prepared lysine and polylysine immobilized affinity membrane chromatography and could reach the adsorption capacities of 17.6-40.7 mg bilirubin /g membrane.

Various polymers such as chitosan, nylon, ethylene vinyl alcohol and etc., have been employed as affinity matrixes for bilirubin separation $[18,25,77]$. Although nylon membranes have high porosity and uniform pores size, but due to the low density of primary amino functional groups in the structure, they do not have the capacity to accept high amount of ligands on their surface. One effective solution which can not only increase the surface active sites, but also improve its hydrophilicity and selectivity is membrane hydrolysis with acid.

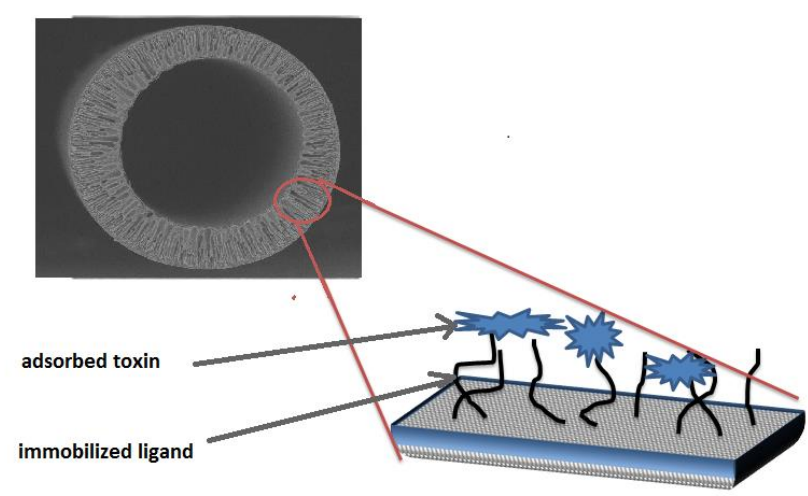

Figure 5 Affinity membrane

Shi et al. [78, 79], immobilized polylysine (PLL) on HEC-coated nylon membranes and removed bilirubin from the bilirubin-albumin solutions effectively. Avramescu et al. [18] employed ethylenevinylalcohol (EVAL) adsorptive membranes using BSA as bio-ligand for bilirubin adsorption. Due to the presence of large amount of active groups on the EVAL membrane, high quantity of BSA could be stabilized on the EVAL membrane. Although, the capability of the BSA-immobilized EVAL membrane to separate bilirubin was not higher than the PLLattached nylon membrane, which may be ascribed to the more density of immobilized PLL compared with BSA. The maximum BR adsorption efficiency that was obtained by using the poly (HEMA-Co-GMA)-PEI affinity membrane developed by Bayramoglu [80], was around $29.7 \mathrm{mg} \mathrm{ml}-1$ which was almost the same as other similar reports. Table 2 gives an overview on the obtained adsorption capacities of different modified membranes, explored in literatures.
Table 2 Comparison of the bilirubin adsorption capacity of different membranes

\begin{tabular}{|c|c|c|c|}
\hline Membrane & $\begin{array}{l}\text { Ligand/ } \\
\text { interaction }\end{array}$ & $\begin{array}{l}\text { Adsorption } \\
\text { capacity } \\
\text { (mg/g) }\end{array}$ & Ref \\
\hline $\begin{array}{c}\text { Chitosan-coupled nylon } \\
\text { membrane }\end{array}$ & $\begin{array}{l}\text { cibacron } \\
\text { Blue } \\
\text { F3GA }\end{array}$ & 64.7 & [25] \\
\hline $\begin{array}{c}\text { Anodic aluminum oxide } \\
\text { (AAO)-silica composite } \\
\text { membrane }\end{array}$ & Lysine (Lys) & 17.57 & [81] \\
\hline $\begin{array}{l}\text { Poly(ethylenevinylalcoh } \\
\text { ol) (EVAL) membranes }\end{array}$ & BSA & 25 & [18] \\
\hline $\begin{array}{l}\text { HEC-coated nylon } \\
\text { membranes }\end{array}$ & PLL & 20 & [78] \\
\hline $\begin{array}{c}\text { chitosan-coated nylon } \\
\text { membranes }\end{array}$ & $\begin{array}{l}\text { polylysine } \\
\text { (PLL) }\end{array}$ & 35 & [77] \\
\hline $\begin{array}{l}\text { HEC-AAO composite } \\
\text { membrane }\end{array}$ & Arginine & 52.6 & [82] \\
\hline $\begin{array}{c}\text { affinity poly (pyrrole-3- } \\
\text { carboxylic acid)- } \\
\text { alumina composite } \\
\text { membrane }\end{array}$ & - & 27.61 & [75] \\
\hline $\begin{array}{l}\text { PEl grafted poly(HEMA- } \\
\text { co-GMA) membrane }\end{array}$ & $\begin{array}{l}\text { Cibacron } \\
\text { Blue } \\
\text { F3GA }\end{array}$ & 29.7 & [80] \\
\hline CA/PEl membrane. & - & 4.6 & [38] \\
\hline $\begin{array}{l}\text { Poly(tetrafluoroethylene } \\
\text { I membrane }\end{array}$ & $\begin{array}{l}\text { Cibacron } \\
\text { Blue } \\
\text { F3GA }\end{array}$ & 76.2 & [83] \\
\hline $\begin{array}{l}\text { Polyacrylonitrile } \\
\text { membrane }\end{array}$ & $\begin{array}{l}\text { Hepatoyct } \\
\text { e } \\
\text { receptor }\end{array}$ & 2.8 & [84] \\
\hline
\end{tabular}

- Hydroxyethyl celluloses (HEC)

- Cellulose acetate (CA) / polyethyleneimine (PEI)

\subsection{CONCLUSION}

Direct contact of blood with the adsorbents, which are considered as the main part of the extracorporeal detoxification systems, not only can separate hydrophobic albumin-bound toxins but also may adsorb some of the plasma proteins and consequently disturb the body equilibrium $[85,86]$. Therefore, frequent using these adsorbents cannot be feasible.

On the other hand, in order to solve the problems such as fouling, reduced flow rate during passing through the column and also preparing a highly packed column composed of adsorbent materials (i.e., beads), scientists reduced the beads diameter, but those adsorbents also needed difficult packing procedure that could deteriorate the mass-transfer rate and extend the treatment time in hemoperfusion, that limited bead applications. Despite the advantages of membrane adsorbents such as high mass-transfer rate and separation performance, they also have their own serious disadvantages. Low packing density of hollow fiber membranes could be resulted in huge interstitial 
volumes. Stacked flat membranes also need high volume and some additional facilities to distribute solutions into the interstitial spaces and improve the perfusion rate. Hence, future developments in blood purification need to focus more on operating factors in order to better understand the transport phenomenon and separation performance and finally can make new breakthroughs for treatment of hyperbilirubinemia.

\section{Acknowledgment}

The authors would like to thank the Faculty of New Sciences and Technologies, University of Tehran and also Advanced Membrane Technology Research Center (AMTEC), Universiti Teknologi Malaysia for their scientific help during the preparation of this review.

\section{References}

[1] Stange, J., T. I. Hassanein, R. Mehta, S. R. Mitzner and R. H. Bartlett. 2002. The Molecular Adsorbents Recycling System as a Liver Support System Based on Albumin Dialysis: A Summary of Preclinical Investigations, Prospective, Randomized, Controlled Clinical Trial, and Clinical Experience From 19 Centers. Artif Organs. 26: 103-110.

[2] Daas, M., D. J. Plevak, E. F. Wijdicks, J. Rakela, R. H. Wiesner, D. G. Piepgras, W. F. Dunn and J. L. Steers. 1995. Acute Liver Failure: Results of a 5-Year Clinical Protocol. Liver Transpl Surg. 1: 210-219.

[3] Karp, W. B. 1979. Biochemical Alterations in Neonatal Hyperbilirubinemia and Bilirubin Encephalopathy: A Review. Pediatrics. 64: 361-368.

[4] Hauser, S. C., J. C. Ziurys and J. L. Gollan. 1986. Regulation of Bilirubin Glucuronide Synthesis in Primate (Macaca Fascicularis) Liver. Kinetic Analysis of Microsomal Bilirubin Uridine Diphosphate Glucuronyltransferase. Gastroenterology. 91: 287-296.

[5] Schwesinger, W. H. and W. E. Kurtin.1983. Changes in Serum and Bile Bilirubin Induced by Acute hemolysis. J Surg Res. 35: 520-524.

[6] Gourley, G. R. 1997. Bilirubin Metabolism and Kernicterus. Adv Pediatr. 44: 173-229.

[7] Hansen, T. W. R. and D. Bratlid.1986. Bilirubin and Brain Toxicity. Acta Paediatrica. 75: 513-522.

[8] Ennever, J. F. 1988. Phototherapy for Neonatal Jaundice. Photochem Photobiol. 47: 871-876.

[9] Meyer, T. W. 2012. The Removal of Protein-bound Solutes by Dialysis. Journal of Renal Nutrition. 22: 203-206.

[10] Vienken, J. and H. Christmann. 2006. How Can Liver Toxins be Removed? Filtration and Adsorption with the Prometheus System. Therapeutic Apheresis and Dialysis. 10: 125-131.

[11] Khurshid, I., L. Anderson, G. H. Downie and G. S. Pape. 2002. Sickle Cell Disease, Extreme Hyperbilirubinemia, and Pericardial Tamponade: Case Report and Review of the Literature. Crit Care Med. 30: 2363-2367.

[12] Trey, C., D. G. Burns and S. J. Saunders. 1966. Treatment of Hepatic Coma by Exchange Blood Transfusion. N Engl J Med. 274: 473-481.

[13] Lepore, M. J. and A. J. Martel. 1970. Plasmapheresis with Plasma Exchange in Hepatic Coma. Methods and Results in Five Patients with Acute Fulminant Hepatic Necrosis. Ann Intern Med. 72: 165-174.

[14] Lepore, M. J., L. J. Stutman, C. A. Bonanno, E. F. Conklin, J. G. Robilotti, Jr. and P. J. McKenna. 1972. Plasmapheresis with Plasma Exchange in Hepatic Coma. II. Fulminant Viral Hepatitis as a Systemic Disease. Arch Intern Med. 129: 900-907.

[15] Buckner, C.D., R.A. Clift, W. Volwiler, D.M. Donohue, J.M. Burnell, F.C. Saunders and E.D. Thomas. 1973. Plasma
Exchange in Patients with Fulminant Hepatic Failure. Arch Intern Med. 132: 487-492.

[16] Guo, W., Z. Shang, Y. Yu and L. Zhou. 1994. Membrane Affinity Chromatography of Alkaline Phosphatase. Journal of Chromatography A. 685: 344-348.

[17] Avramescu, M. E., W. F. Sager, Z. Borneman and M. Wessling. 2004. Adsorptive Membranes for Bilirubin Removal. J Chromatogr B Analyt Technol Biomed Life Sci. 803: $215-223$

[18] Denizli, A. and E. Pişkin. 2001. Dye-ligand Affinity Systems. Journal of Biochemical and Biophysical Methods. 49: 391416.

[19] Brodersen, R. 1979. Bilirubin. Solubility And Interaction with Albumin and Phospholipid. J Biol Chem. 254: 2364-2369.

[20] Jin, G., Q. Yao, S. Zhang and L. Zhang. 2008. Surface Modifying of Microporous PTFE Capillary for Bilirubin Removing from Human Plasma and Its Blood Compatibility. Materials Science and Engineering: C. 28 : 1480-1488.

[21] Romagnoli, C., G. Polidori, M. Foschini, L. Cataldi, P. De Turris, G. Tortorolo and R. Mastrangelo. 1975. Agar in the Management of Hyperbilirubinaemia in the Premature Baby. Arch Dis Child. 50: 202-204.

[22] Lauterburg, B. H., E. R. Dickson, A. A. Pineda, G. L. Carlson and H. F. Taswell. 1979. Removal of Bile Acids and Bilirubin by Plasmaperfusion of U.S.P. Charcoal-coated Glass Beads. J Lab Clin Med. 94: 585-592.

[23] Chandy, T. and C. P. Sharma. 1992. Polylysine-immobilized Chitosan Beads as Adsorbents for Bilirubin. Artif Organs. 16:568-576.

[24] Xia, B., G. Zhang and F. Zhang. 2003. Bilirubin Removal by Cibacron Blue F3GA Attached Nylon-based Hydrophilic Affinity Membrane. Journal of Membrane Science. 226: 920.

[25] Alvarez, C., M. Strumia and H. Bertorello. 2001. Synthesis and Characterization of a Biospecific Adsorbent Containing Bovine Serum Albumin as a Ligand and Its Use for Bilirubin Retention. J Biochem Biophys Methods. 49: 649-656.

[26] Lopukhin, U. M., B. K. Shurkalin, U. A. Leykin, N. G. Evseev, M. N. Molodenkov, V. N. Kuznetzov, V. D. Gorchakov and A. S. Blagosklonov. 1975. Letter: Bilirubin Removal by Anion-Exchange Resin. Lancet. 2: 461.

[27] YU, Y. H. and B. L. He. 1996. A New Type of ALSS - The Preparation of Crosslinked Chitosan Resins and Its Adsorption Properties for Bilirubin. Reactive and Functional Polymers. 31: 195-200.

[28] Si, S., L. Si, F. Ren, D. Zhu and Y. Fung. 2002. Study of Adsorption Behavior of Bilirubin on Human-Albumin Monolayer Using A Quartz Crystal Microbalance. J Colloid Interface Sci. 253: 47-52.

[29] Davies, C. R., P. S. Malchesky and G. M. Saidel. 1990. Temperature and Albumin Effects on Adsorption of Bilirubin from Standard Solution Using Anion-exchange Resin. Artif Organs. 14: 14-19.

[30] Komissarova, L. K., A. A. Kuznetsov, N. P. Gluchoedov, M. V. Kutushov and M. A. Pluzan. 2001. Absorptive Capacity of Iron-based Magnetic Carriers for Blood Detoxification. Journal of Magnetism and Magnetic Materials. 225: 197201.

[31] Syu, M.J., J.H. Deng and Y.M. Nian. 2004. Towards bilirubin imprinted poly(methacrylic acid-co-ethylene glycol dimethylacrylate) for the specific binding of a-bilirubin. Analytica Chimica Acta. 504: 167-177.

[32] Wang, H., J. Ma, Y. Zhang and B. He. 1997. Adsorption of Bilirubin on the Polymeric B-Cyclodextrin Supported by Partially Aminated Polyacrylamide Gel. Reactive and Functional Polymers. 32: 1-7.

[33] Wu, G. and G. Brown. 1991. Adsorption of Bilirubin by Amine-Containing Polyacrylamide Resins. Reactive Polymers. 14: 49-61.

[34] Henning, D. S., G. R. Brown and L. E. St-Pierre. 1986. Polymer Resins with Amino Acid Containing Pendants for Sorption of Bilirubin. II. Polyamide Resins with Various Basic Amino Acids. Int J Artif Organs. 9: 33-38.

[35] Zhu, X. X., G. R. Brown and L. E. St-Pierre. 1990. Adsorption of Bilirubin with Polypeptide-coated Resins. Biomater Artif Cells Artif Organs. 18: 75-93. 
[36] Kocakulak, M., A. Denizli, A. Y. Rad and E. Piskin. 1997. New Sorbent for Bilirubin Removal from Human Plasma: Cibacron Blve F3GA-immobilized poly(EGDMA-HEMA) Microbeads. Journal Chromatogr B Biomed Sci Appl. 693: $271-276$.

[37] Ju, J., G. He, Z. Duan, W. Zhao, Y. Liu, L. Zhang and Y. Li. 2013. Improvement of Bilirubin Adsorption Capacity of Cellulose Acetate/Polyethyleneimine Membrane Using Sodium Deoxycholate. Biochemical Engineering Journal. 79: 144-152.

[38] Brian, B. F., W. J. Dorson, V. B. Pizziconi, P. J. Ramseyer and J. E. Brooker. 1988. Augmented Hemoperfusion for Hyperbilirubinemia. ASAIO Trans. 34: 585-589.

[39] Tang, T., X. Li, Y. XU, D. WU, Y. Sun, J. Xu and F. Deng. 2011. Bilirubin Adsorption on Amine/Methyl Bifunctionalized SBA-15 with Platelet Morphology. Colloids Surf B Biointerfaces. 84: 571-578.

[40] Quaglia, M., E. De Lorenzi, C. Sulitzky, G. Caccialanza and B. Sellergren. 2003. Molecularly Imprinted Polymer Films Grafted from Porous or Nonporous Silica: Novel Affinity Stationary Phases in Capillary Electrochromatography. ELECTROPHORESIS. 24: 952-957.

[41] Yang, Y., Y. Long, Q. Cao, K. Li and F. Liu. 2008. Molecularly Imprinted Polymer Using Beta-Cyclodextrin as Functional Monomer for the Efficient Recognition of Bilirubin. Anal Chim Acta. 606: 92-97.

[42] Syu, M. J., Y. M. Nian, Y. S. Chang, X. Z. Lin, S. C. Shiesh and T. C. Chou. 2006. Ionic Effect on the Binding of Bilirubin to the Imprinted Poly(Methacrylic Acid-CoEthylene Glycol Dimethylacrylate). Journal of Chromatography A. 1122: 54-62.

[43] Wu, A. H. and M. J. Syu. 2006. Synthesis of Bilirubin Imprinted Polymer Thin Film for the Continuous Detection of Bilirubin in an MIP/QCM/FIA System. Biosensors and Bioelectronics. 21: 2345-2353.

[44] Baydemir, G., N. Bereli, M. Andac, R. Say, I.Y. Galaev and A. Denizli. 2009. Bilirubin Recognition Via Molecularly Imprinted Supermacroporous Cryogels. Colloids Surf B Biointerfaces. 68: 33-38.

[45] Zimmerman, S. C. and N. G. Lemcoff. 2004. Synthetic Hosts Via Molecular Imprinting-Are Universal Synthetic Antibodies Realistically Possible? Chemical Communications. 5-14.

[46] Song, C., A. Zhang, W. Shi, H. Jiang and D. Ge. 2011. Functionalized Silica Nanotubes As Affinity Matrices for Bilirubin Removal. Nanotechnology, IEEE Transactions on. 10: 626-631

[47] Zhang, L. and G. Jin. 2006. Novel Method for Bilirubin Removal from Human Plasma within Modified Polytetrafluoroethylene Capillary. Reactive and Functional Polymers. 66: 1106-1117.

[48] Wei, H., L. XU, J. Ren and L. Jia. 2012. Adsorption of Bilirubin to Magnetic Multi-walled Carbon Nanotubes as a Potential Application in Bound Solute Dialysis. Colloids and Surfaces A: Physicochemical and Engineering Aspects. 405: 38-44.

[49] Yang, Z., S. Si and Y. Fung. 2007. Bilirubin Adsorption on Nanocrystalline Titania Films. Thin Solid Films. 515: 33443351

[50] Syu, M. J., J. H. Deng, Y. M. Nian, T.C. Chiu and A.H. Wu. 2005. Binding specificity of a-bilirubin-imprinted poly (methacrylic acid-co-ethylene glycol dimethylacrylate) toward a-bilirubin. Biomaterials. 26: 4684-4692.

[51 Baydemir, G., M. Andaç, N. Bereli, R. Say and A. Denizli. 2007. Selective Removal of Bilirubin from Human Plasma with Bilirubin-Imprinted Particles. Industrial \& Engineering Chemistry Research. 46: 2843-2852.

[52] Baydemir, G., N. Bereli, M. Andaç, R. Say, I. Y. Galaev and A. Denizli. 2009. Supermacroporous Poly (Hydroxyethyl Methacrylate) based Cryogel with Embedded Bilirubin Imprinted Particles. Reactive and Functional Polymers. 69: 36-42.

[53] Şenel, S., F. Denizli, H. Yavuz ad A. Denizli. 2002. Bilirubin Removal from Human Plasma by Dye Affinity Microporous Hollow Fibers. Separation Science and Technology. 37: 1989-2006.

[54] Altıntaş, E. B., D. Türkmen, V. Karakoç and A. Denizli. 2011. Efficient Removal of Bilirubin from Human Serum by
Monosize Dye Affinity Beads. Journal of Biomaterials Science, Polymer Edition. 22: 957-971.

[55] Yamazaki, K., K. Shinke and T. Ogino. 2013. Selective Adsorption of Bilirubin Against Albumin to Oxidized SingleWall Carbon Nanohorns. Colloids and Surfaces B: Biointerfaces. 112: 103-107.

[56] Gao, B., H. Lei, L. Jiang and Y. Zhu. 2007. Studies on Preparing and Adsorption Property of Grafting Terpolymer Microbeads of PEI-GMA/AM/MBA for Bilirubin. Journal of Chromatography B. 853: 62-69.

[57] Timin, A., E. Rumyantsev and A. Solomonov. 2014. Synthesis and Application of Amino-Modified Silicas Containing Albumin as Hemoadsorbents for Bilirubin Adsorption. Journal of Non-Crystalline Solids. 385: 81-88.

[58] Timin, A. S., A. V. Solomonov and E. V. Rumyantsev. 2014 Polyacrylate Guanidine and Polymethacrylate Guanidine as Novel Cationic Polymers for Effective Bilirubin Binding Journal of Polymer Research. 21: 1-9.

[59] Ma, Z., M. Kotaki and S. Ramakrishna. 2005. Electrospun Cellulose Nanofiber as Affinity Membrane. Journal of Membrane Science. 265: 115-123.

[60] Guo, L., L. Zhang, J. Zhang, J. Zhou, Q. He, S. Zeng, X. Cui and J. Shi. 2009. Hollow Mesoporous Carbon Spheres-An Excellent Bilirubin Adsorbent. Chemical Communications. 6071-6073.

[61] Timin, A. S., E. V. Rumyantsev, A. V. Solomonov, I. I. Musabirov, S. N. Sergeev, S. P. Ivanov, G. Berlier and E. Balantseva. 2015. Preparation and Characterization of Organo-Functionalized Silicas for Bilirubin Removal. Colloids and Surfaces A: Physicochemical and Engineering Aspects. 464: 65-77.

[62] Timin, A., E. Rumyantsev, S. N. Lanin, S.A. Rychkova, S. S. Guseynov, A. V. Solomonov and E. V. Antina. 2014 Preparation and Surface Properties of Mesoporous Silica Particles Modified with Poly (N-vinyl-2-pyrrolidone) as a Potential Adsorbent for Bilirubin Removal. Materials Chemistry and Physics. 147: 673-683.

[63] Denizli, A., M. Kocakulak and E. Pişkin. 1998. Bilirubin Removal from Human Plasma in a Packed-Bed Column System with Dye-Affinity Microbeads. Journal of Chromatography B: Biomedical Sciences and Applications. 707: 25-31.

[64] Rad, A. Y., H. Yavuz, M. Kocakulak and A. Denizli. 2003. Bilirubin Removal from Human Plasma with Albumin Immobilised Magnetic Poly (2-hydroxyethyl methacrylate) Beads. Macromolecular Bioscience. 3: 471-476.

[65] Uzun, L. and A. Denizli. 2006. Bilirubin Removal Performance of Immobilized Albumin in a Magnetically Stabilized Fluidized Bed. Journal of Biomaterials Science, Polymer Edition. 17: 791-806.

[66] Weber, V., I. Linsberger, M. Hauner, A. Leistner, A. Leistner and D. Falkenhagen. 2008. Neutral Styrene Divinylbenzene Copolymers for Adsorption of Toxins in Liver Failure. Biomacromolecules. 9: 1322-1328.

[67] Han, X.y. and Z.p. Zhang. 2009. Preparation of Grafted Polytetrafluoroethylene Fibers and Adsorption of Bilirubin. Polymer International. 58: 1126-1133.

[68] Ando, K., K. Shinke, S. Yamada, T. Koyama, T. Takai, S. Nakaji and T. Ogino. 2009. Fabrication of Carbon Nanotube Sheets and Their Bilirubin Adsorption Capacity. Colloids and Surfaces B: Biointerfaces. 71: 255-259.

[69] Ko, Y. M., C. I. Chen, C. J. Shieh and Y. C. Liu. 2012 Simultaneous Purification and Immobilization of DHydantoinase on the Immobilized Metal Affinity Membrane Via Coordination Bonds. Biochemical Engineering Journal. 61: 20-27.

[70] Klein, E. 2000. Affinity Membranes: A 10-Year Review. Journal of Membrane Science. 179: 1-27.

[71] Shi, W., Y. Shen, D. Ge, M. Xue, H. Cao, S. Huang, J. Wang, G. Zhang and F. Zhang. 2008. Functionalized Anodic Aluminum Oxide (AAO) Membranes for Affinity Protein Separation. Journal of Membrane Science. 325: 801-808.

[72] Ge, D., W. Shi, L. Ren, F. Zhang, G. Zhang, X. Zhang and Q. Zhang. 2006. Variation Analysis of Affinity-Membrane Model Based on Freundlich Adsorption. Journal of Chromatography A. 1114 : 40-44.

[73] Shi, W., H. Cao, C. Song, H. Jiang, J. Wang, S. Jiang, J. Tu and D. Ge. 2010. Poly (pyrrole-3-carboxylic acid)-alumina 
Composite Membrane for Affinity Adsorption of Bilirubin. Journal of Membrane Science. 353: 151-158.

[74] Shi, W. F. Zhang and G. Zhang. 2005. Mathematical Analysis of Affinity Membrane Chromatography. Journal of Chromatography A. 1081: 156-162.

[75] Shi, W., F. Zhang and G. Zhang. 2005. Adsorption of Bilirubin with Polylysine Carrying Chitosan-Coated Nylon Affinity Membranes. Journal of Chromatography B. 819: 301-306.

[76] Shi, W., F. Zhang, G. Zhang, L. Jiang, Y. Zhao and S. Wang. 2003. Polylysine-immobilized Affinity Nylon Membrane Used for Bilirubin Adsorption. Molecular Simulation. 29: 787-790.

[77] Shi, W., F. Zhang, G. Zhang, D. Ge and Q. Zhang. 2005. Adsorption of Bilirubin on Poly-L-Lysine-Containing Nylon Membranes: Applications in Affinity Chromatography. Polymer International. 54: 790-795.

[78] Bayramoğlu, G., E. Yalçın and M. Y. Arıca. 2005. Characterization of Polyethylenimine Grafted and Cibacron Blue F3GA Immobilized Poly (hydroxyethylmethacrylate-co-glycydylmethacrylate) Membranes and Application to Bilirubin Removal from Human Serum. Colloids and Surfaces A: Physicochemical and Engineering Aspects. 264: 195-202.
[79] Shi, W. Y. Shen, H. Jiang, C. Song, Y. Ma, J. Mu, B. Yang and D. Ge. 2010. Lysine-attached Anodic Aluminum Oxide (AAO)-silica Affinity Membrane for Bilirubin Removal. Journal of Membrane Science. 349: 333-340.

[80] Xue, M., Y. Ling, G. Wu, X. Liu, D. Ge and W. Shi. 2013. Surface-modified Anodic Aluminum Oxide Membrane with Hydroxyethyl Celluloses as a Matrix for Bilirubin Removal. Journal of Chromatography B. 912: 1-7.

[81] Zhang, L. and G. Jin. 2005. Bilirubin Removal from Human Plasma by Cibacron Blue F3GA using Immobilized Microporous Affinity Membranous Capillary Method. Journal of Chromatography B. 821: 112-121.

[82] Chernova, I. and K.Y. Gurevich. 1996. Structure and Sorption Characteristics of Bioaffinity membranes. Journal of Membrane Science. 113: 161-167.

[83] Winchester, J. F., J. M. MacKay, C. D. Forbes, J. M. Courtney, T. Gilchrist and C. R. Prentice. 1978. Hemostatic Changes Induced in Vitro by Hemoperfusion Over Activated Charcoal. Artificial Organs. 2: 293-300.

[84] Malchesky, P. S. 1994. Nonbiological Liver Support: Historic Overview. Artificial Organs. 18: 342-347. 